\title{
INVESTIGATION OF MILK YIELD FROM CULTURE, CROSS- BRED AND NATIVE CATTLE BREEDS IN TURKEY BY MULTIVARIATE ANALYSIS OF VARIANCE (MANOVA)
}

\author{
AZAK, G. - CELIK, S.* \\ Department of Animal Science, Faculty of Agriculture, Biometry and Genetics, Bingol \\ University, Bingol, Turkey \\ *Corresponding author \\ e-mail: senolcelik@bingol.edu.tr; phone: +90-505-217-7021 \\ (Received $21^{\text {st }}$ Jun 2019; accepted $16^{\text {th }}$ Oct 2019)
}

\begin{abstract}
In this study, milk yield from culture, cross-bred, and native cattle breeds in 7 geographical regions of Turkey were investigated by multivariate analysis of variance (MANOVA) in 2015. The values of Pillai's Trace, Wilks' Lambda, Hotelling's Trace and Roy's Largest Root statistics used for the MANOVA test were $0.522,0.546,0.711$ and 0.490 , respectively. The corresponding $\mathrm{F}$ values for these statistics were found to be $2.422,2.518,2.594$ and 5.634, respectively. Mean annual milk yield of crossbred, culture, and native cattle breeds reached to be $3776.355,2692.803$ and $1311.513 \mathrm{~kg}$, respectively. Therefore, the results of these statistics are very close to each other. As a result of the MANOVA test, the difference within milk yield between the regions was not significant for culture and native cattle breeds, whereas a significant difference was found in hybrid breed cattle $(\mathrm{P}<0.001)$. As a result of the Bonferroni test, it was found that the milk yield difference in hybrid cattle was due to the difference in yield between Eastern Anatolia-Aegean, Eastern Anatolia-Marmara, Southeast Anatolia-Aegean and Southeast Anatolia-Marmara regions.
\end{abstract}

Keywords: Wilks' Lambda, outlier, race, milk yield, geographical region

\section{Introduction}

Production of animal products and per capita consumption of animal products are among the indicators of the development level of a country (Şapdeniz, 1993). Milk is one of the most important animal products. It is an essential nutrient for a sufficient and balanced human diet and for fulfilling the protein need of the ever-growing world population. Milk consumption is significant in the diets of people of all ages. Although milk has a key role in human diet and per capita consumption of milk has been on the rise in Turkey in recent years, it has not reached to a desired level yet (Akman, 2017).

Turkey has a great potential for increasing animal production due to its geographical position and land structure favorable for animal breeding. While Turkey ranks among the leading countries in terms of animal numbers, the yield per animal is not at a desired level. Therefore, researches performed in Turkey aim to improve the yield obtained per animal rather than to increase the number of animals (Yaylak, 2003). In the republican period, culture breeding cattle were imported from abroad for the improvement of the indigenous breeds. Cattle import activities, which started in the republican period, have continued until today. Currently, $88 \%$ of the cattle population consists of culture breeds and cross breeds. While the number of indigenous breeds has continuously reduced in the whole cattle population, the number of cross breeds has shown a significant increase. In researches performed to improve the milk yield obtained from cattle in Turkey, culture cattle breeding has been prioritized since 1958 (Kumlu and Akman, 1999). 
In researches on dairy cattle breeding in Turkey, the improvements in milk production, the effects of environmental and genotypic factors and the rate of these factors were emphasized (Alpan and Arpacik, 1998). Milk yield in cattle is affected by two factors, which are; the genotype of the animal and favorable environmental conditions (Tuncel, 1994). Breeding methods and selection are used to improve the milk yield capacity in terms of genetics. On the other hand, environmental factors can lead to long-term and daily changes.

Age, breed, live weight, lactation method, number of daily milking, feeding, ambient temperature, calving season, duration of dry period, diseases and exercises are among the factors that affect milk yield in cows.

In Turkey and in other countries, various researches have been performed on 305-day milk yield of the Holstein Friesian cattle (Table 1).

Table 1. 305-day milk yield of the Holstein Friesian cattle in Turkey and in other countries

\begin{tabular}{c|c|c|c}
\hline Year and authors & Country & Average milk yield & Number of animals \\
\hline Türkyılmaz (2005) & Turkey & 6491 & 544 \\
Sattar et al. (2005) & Turkey & 2772 & 499 \\
Tekerli and Gündoğan (2005) & Turkey & 6404 & 525 \\
Bakır et al. (2009) & Turkey & 6810 & 1302 \\
Şahin and Ulutaş (2010) & Turkey & 6976 & 536 \\
Keskin and Boztepe (2011) & Turkey & 5997 & 105 \\
Duru et al. (2012) & Turkey & 6010 & 597 \\
Boğakşayan and Bakır (2013) & Turkey & 5673 & 1935 \\
Khattab et al. (2005) & Egypt & 4746 & 2095 \\
Makgahlela et al. (2007) & South Africa & 8695 & 4112 \\
Hashemi and Nayebpoor (2008) & Iran & 5123 & 19885 \\
Oudah and Zainab (2010) & Egypt & 2737 & 1011 \\
Pirzada (2011) & UK & 7743 & 10768 \\
Yousefi-Golverdi et al. (2012) & Iran & 5662 & 1128 \\
Bastin et al. (2013) & Belgium & 8851 & 52147 \\
Irano et al. (2014) & Brazil & 9001 & 5090 \\
Kheirabadi and Alijani (2014) & Iran & 9059 & 763505 \\
\hline
\end{tabular}

According to the Turkish Statistical Institute (TSI), while the number of cattle in Turkey was the highest in 1981 (15981 000), the number was 13994071 in 2015. This indicates that, whereas Turkey had an important cattle potential in the past, this potential has reduced later. According to the statistics of the year 2015; 16933520 $(90.77 \%)$ tones of the 18.654 .682 tones milk annually produced in Turkey, were obtained from cattle (TSI, 2015). In this respect, cattle milk has an increased value as it has the highest share.

$5.58 \%$ of the milk obtained from cattle was from indigenous breeds, $37.30 \%$ of it was from cross breeds and $57.12 \%$ of it was from culture breeds. As for the annual milk yield from cattle; around $1307 \mathrm{~kg}$ was from indigenous breeds, around $2677 \mathrm{~kg}$ was from cross breeds, around 3743 was from culture breeds and it was around $2581 \mathrm{~kg}$ in general (TSI, 2015). 
According to FAO (2017), cattle breeding is most common in Brazil with $214,889,796$ animals. India ranks second with $185,103,532$ animals and the USA ranks third with 93,704,600 animals. Turkey ranks twenty third in the world with 14 080155 cattle. FAO (2017) also reported that, the USA ranks first in cattle milk production with 97734736 tones, India ranks second with 83,633,570 tones and Brazil ranks third with $33,490,810$ tones. Turkey ranks ninth in the world by producing 18762319 tones cattle milk. These indicate that Turkey has a key role in cattle milk production.

The aim of the study is to examine the milk yields from indigenous, cross and culture breeds in 7 geographical regions of Turkey and to analyze the region-based variations in yearly milk yield.

\section{Materials and methods}

\section{Material}

Research material consisted of information obtained from the website of the Turkish Statistical Institute (TSI) with regards to the number of indigenous, cross and culture breeds cattle and the milk yield from these cattle, as presented on provincialbasis for the year 2015. Turkey Statistical Institute (TSI) of the data compiled by the relevant institutions (Ministry of Agriculture and Forestry) were taken from the records.

The amount of milk obtained from the cities of 7 geographical regions in Turkey was divided by the number of cattle milked, in order to calculate the average yearly milk yield. The values obtained were individually identified and analyzed for indigenous, cross and culture breeds. Statistical evaluations were made using IBM SPSS version 23.

\section{Method}

Multivariate analysis is performed when there are 2 or more dependent variables in each group with 2 or more members. In other words, mean vectors of more than 2 groups (in k) are compared (Alpar 2011). Comparison of the mean vector of $\mathrm{k}$ population for the MANOVA model (Eq. 1; Johnson and Wichern 2002):

$$
Y_{i j k}=\mu+\alpha_{i j}+\varepsilon_{i j k}
$$

here, $Y_{i j k}$ : is the k. observed value of the $\mathrm{j}$. variable in i. population, $\alpha_{i j}$ : is the effect of $\mathrm{j}$. variable in $\mathrm{i}$. population, $\varepsilon_{\mathrm{ijk}}$ : is the error value in observed $\mathrm{k}$. of the $\mathrm{j}$. variable in i. Population.

Error terms $\left(\varepsilon_{\mathrm{ijk}}\right)$ have a normal distribution that are independent of each other, with zero means and $\sum$ covariance matrix (Jeremy 1974). $\bar{x}_{i}$ : is the mean vector of $i$. group, $\bar{x}$ : is the general mean vector, $n_{i}$ : is the number of observations in i. group, $S_{\mathrm{i}}$ : is the variance-covariance vector in i. group (Eqs. 2 and 3):

$$
\begin{gathered}
B=\sum_{i=1}^{k} n_{i}\left(\bar{x}_{i}-\bar{x}\right)\left(\bar{x}_{i}-\bar{x}\right)^{\prime} \\
W=\sum_{i=1}^{k}\left(n_{i}-1\right) S_{i}
\end{gathered}
$$


Eigenvalues of the $B W^{-1}$ matrix are $\lambda_{i}$. The largest root test statistics of Roy is the highest $\lambda_{i}$ value.

Lawley-Hotelling trace test (Eq. 4):

$$
T_{0}^{2}=\sum_{i=1}^{s} \lambda_{i}
$$

Pillai's Trace statistics (Eq. 5; Lehmann 1986):

$$
T=\sum_{i=1}^{s} \lambda_{i} /\left(1+\lambda_{i}\right)
$$

Here, $\mathrm{s}$ is the eigenvalue number. Wilks Lambda statistic is developed by Rao (1973) and is shown as (Eq. 6):

$$
\Lambda=\prod_{i=1}^{s} 1 /\left(1+\lambda_{i}\right)
$$

One of the key hypotheses needed for the implementation of the multivariate analysis (MANOVA) is the homogeneity of the variance-covariance matrices. This is determined by the 'Box's M' test (Eq. 7).

$$
M=\sum_{i=1}^{k}\left(n_{i}-1\right) \ln |S|-\sum_{i=1}^{k}\left(n_{i}-1\right) \ln \left|S_{i}\right|
$$

In this Box's $M$ statistic, $S$ is the covariance matrix, $S_{i}$ is the covariance matrix of each group (Özdamar 2013). For the multiple comparisons, paired comparisons regarding the Bonferroni approach are made in order to form simultaneous confidence intervals (Hsu 1996; Everitt 2001). Multiple test statistics are used in the multivariate analysis in order to test the $\mathrm{H}_{\mathrm{o}}$ hypothesis. The Wilks Lambda test statistic presenting $\mathrm{F}$ distribution when the number of variables become 1,2 for the first time, is the most common among these test statistics and calculated as such:

Wilks Lamda test statistic; Equation 8 used in the calculation of the test variate $\mathrm{F}$ statistic is written as:

$$
1+\frac{\text { G.A.K.O }}{\text { G.I.K.O }}
$$

and inverted for the multivariate $\mathrm{B}$ and $\mathrm{W}$ matrices, to obtain (Eq. 9):

$$
\frac{1}{1+\frac{G \cdot A \cdot K \cdot O}{G \cdot \dot{\mathrm{L}} \cdot K \cdot O}}=\frac{1}{1+\frac{B}{W}}=\frac{|W|}{|B+W|}=\Lambda
$$

The $\Lambda$ statistic here is called as the Wilks Lambda statistic.

In multivariate analysis, this ratio is used in place of the F statistic used in univariate analysis and takes a value between 0 and 1 . If there is no group effect, $\Lambda$ value is 1 if $\mathrm{B}=0$. Accordingly, the Ho hypothesis is accepted when $\Lambda$ gets a value close to 1 . If matrix $\mathrm{B}$ is bigger than matrix $\mathrm{W}, \Lambda$ value gets closer to zero (0). In this case, the Ho hypothesis is rejected. As in univariate analysis, there is a correlation between $\Lambda$ and $\mathrm{T}^{2}$ in multivariate analysis, too.

When $\mathrm{k}=2$ (Eq. 10): 


$$
\Lambda=\frac{1}{1+\frac{T^{2}}{N-k}}
$$

When $\mathrm{k}=2, \Lambda$ and $\mathrm{T}^{2}$ statistics show $\mathrm{p}$ and $\mathrm{N}-\mathrm{p}-1$ freedom degree $\mathrm{F}$ distribution.

When $\mathrm{p}=1($ Eq. 11):

$$
\Lambda=\frac{1}{1+B / W}=\frac{B}{W} \frac{N-k}{k-1}=F
$$

\section{Results and discussion}

Normal distribution of data and covariance matrices homogeneity test were performed based on the hypotheses needed for the covariate analysis (MANOVA). Outlier observations were found in the normality test (Fig. 1). Box's Test was performed in the equalities of covariance matrices.

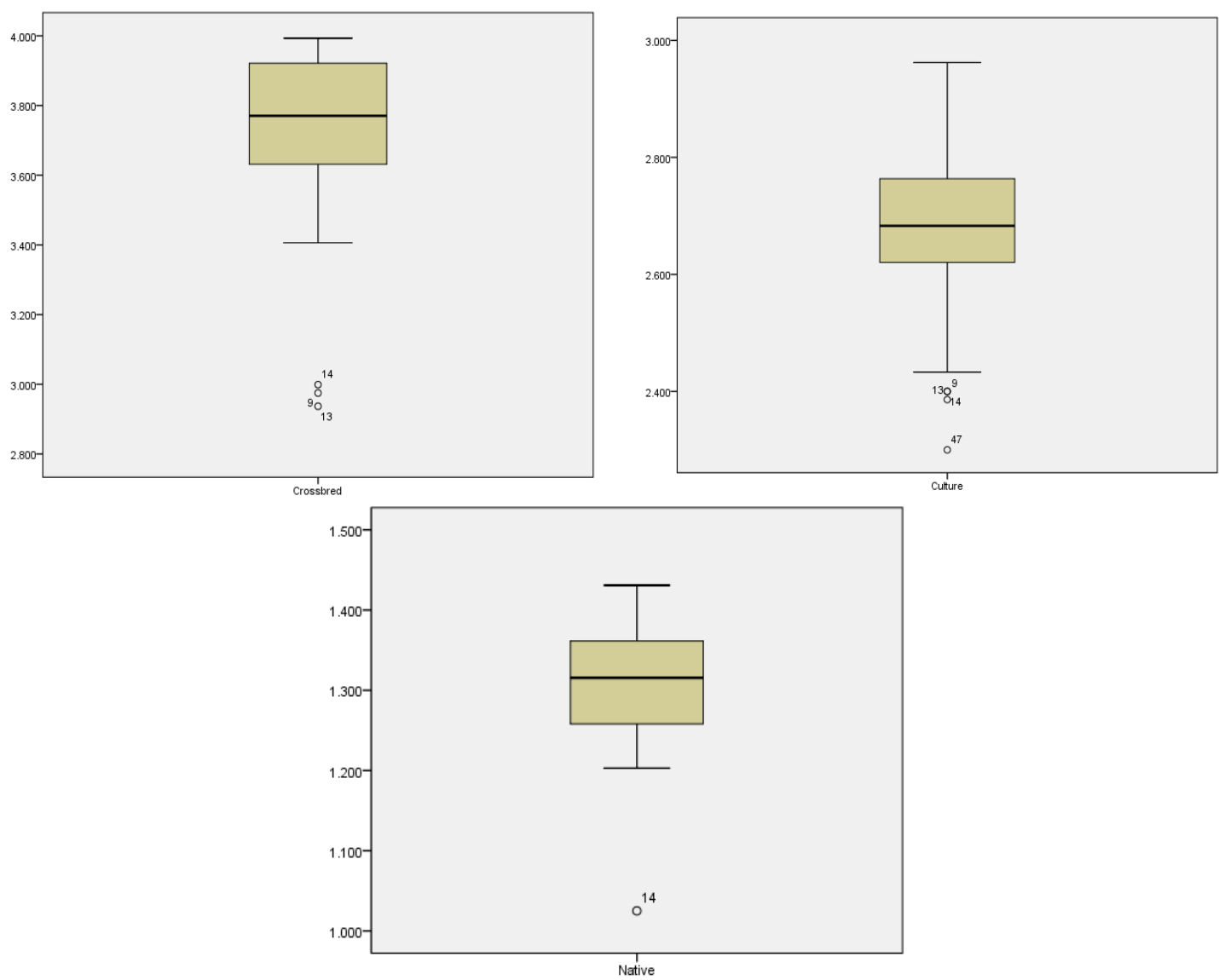

Figure 1. Outlier observation graph of data (yield-kg)

As is seen in Figure 1, milk yield data of cross, culture and indigenous cattle show a normal distribution. In cross breed group, $9^{\text {th }}, 13^{\text {th }}$ and $14^{\text {th }}$ values are the outliers; in culture group, $9^{\text {th }}, 13^{\text {th }}, 14^{\text {th }}$ and $47^{\text {th }}$ values are the outliers whereas in indigenous group, $14^{\text {th }}$ value is the outlier. As Box's $\mathrm{M}=74.391, \mathrm{~F}=1.779$ and $\mathrm{p}<0.01$ in Box's M Test as shown in Table 2, covariance matrices are not homogenous. 
Following the obtainment of these results, a reanalysis was performed after the removal of $9^{\text {th }}, 13^{\text {th }}, 14^{\text {th }}$ and $47^{\text {th }}$ outliers from the observed values since they were interrupting normality. The values belonged to the cities of Bingöl, Bitlis, Hakkari and Bartın. For this reason, Kilis, Bingöl, Bitlis, Hakkari and Bartın were excluded from the research and the research was performed with 76 cities. Q-Q Plot and outlier value graphs obtained from the normality tests performed for the new observations are given in Figure 2.
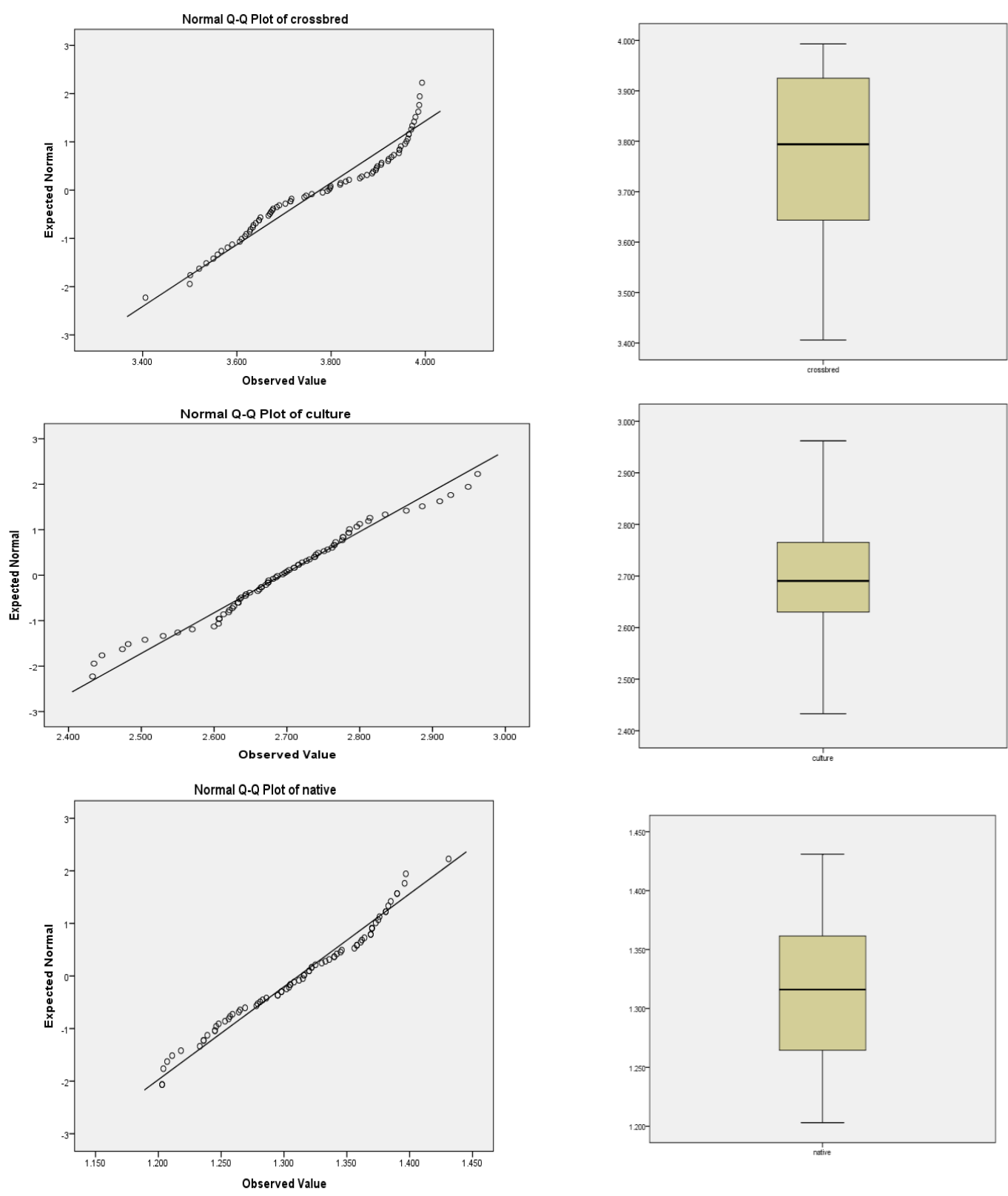

Figure 2. Normal distribution and outlier observation graph of data

As is seen in Figure 2, milk yield from cross, culture and indigenous cattle breeds show normal distribution according to Q-Q plot graph. This indicates that the outlier value problem has been resolved. 
At this point, homogeneity test for the covariance matrices of these data is presented in Table 2 and test for sphericity is presented in Table 3.

Table 2. Box's $M$ Test for the equality of the covariance matrices

\begin{tabular}{c|c}
\hline Box's M & 74.391 \\
$\mathrm{~F}$ & 1.779 \\
$\mathrm{df} 1$ & 36 \\
$\mathrm{df} 2$ & 5667.462 \\
$\mathrm{p}$ & 0.003 \\
\hline
\end{tabular}

df: degrees freedom

Table 3. Box's Test for the equality of covariance matrices of groups

\begin{tabular}{c|c}
\hline Box's M & 57 \\
$\mathrm{~F}$ & 1.356 \\
$\mathrm{df} 1$ & 36 \\
$\mathrm{df} 2$ & 5677.983 \\
$\mathrm{p}$ & 0.076 \\
\hline
\end{tabular}

$\mathrm{H}_{0}: \Sigma 1=\Sigma 2=\Sigma 3 ; \mathrm{H}_{1}$ : At least one of the group mean values is different from the others. Since $\mathrm{p}=0.076>\alpha: 0.05, \mathrm{H}_{0}$ cannot be rejected. Which means; group covariance matrices are equal. Therefore, MANOVA can be performed. In Table 2, Box's M = 57, $\mathrm{F}=1.356$ and $\mathrm{p}>0.05$, indicating that covariance matrices are homogenous. Test for sphericity is checked in Table 4.

Table 4. Bartlett's test for sphericity

\begin{tabular}{c|c}
\hline Likelihood Ratio & 0.000 \\
Approx. Chi-Square & 53.611 \\
$\mathrm{df}$ & 5 \\
$\mathrm{p}$ & 0.001 \\
\hline
\end{tabular}

In Barlett's test for sphericity shown in Table 3, Approx $\chi^{2}=53.611$ and $\mathrm{p}<0.01$, indicating that MANOVA test can be performed. The assumption of normality is provided when the outlier values are omitted. Non-parametric tests are not necessary since appropriate analyzes can be performed with parametric statistics. Descriptive statistics are presented in Table 5. The table presenting representative statistics shows that milk yield from cross, culture and indigenous cattle present inter-regional differences.

The highest milk yield from cross breeds is obtained in the Aegean Region whereas the lowest milk yield is obtained in the Eastern Anatolia Region, the highest milk yield from culture breeds is obtained in the Aegean Region whereas the lowest milk is obtained in the Southeastern Anatolia Region, the highest milk yield from indigenous breeds is obtained in the Eastern Anatolia Regions whereas the lowest milk yield is obtained in the Mediterranean Region. MANOVA test results are presented in Table 6. 
Table 5. Descriptive statistics

\begin{tabular}{c|c|c|c|c|c|c}
\hline Race & Region & $\overline{\boldsymbol{X}}$ & Range $=$ Xmax-Xmin & $\boldsymbol{S}_{\boldsymbol{X}}$ & $\boldsymbol{S}_{\boldsymbol{X}}$ & $\mathbf{N}$ \\
\hline \multirow{5}{*}{ Culture } & Eastern Anatolia & 3670.273 & 163.740 & 100.480 & 41.039 & 11 \\
& Southeastern Anatolia & 3677.625 & 192.002 & 119.105 & 48.122 & 8 \\
& Marmara & 3889.182 & 163.740 & 79.625 & 41.039 & 11 \\
& Aegean & 3926.750 & 192.002 & 64.913 & 48.122 & 8 \\
& Black Sea & 3743.412 & 131.712 & 147.847 & 33.011 & 17 \\
& Central Anatolia & 3796.154 & 150.618 & 186.853 & 37.750 & 13 \\
& Mediterranean & 3753.250 & 192.002 & 175.830 & 48.122 & 8 \\
& General & 3776.355 & 163.740 & 156.156 & & 76 \\
\hline \multirow{5}{*}{ Cross-bred } & Eastern Anatolia & 2715.182 & 135.728 & 153.598 & 34.018 & 11 \\
& Southeastern Anatolia & 2624.250 & 159.156 & 104.321 & 39.890 & 8 \\
& Marmara & 2699.818 & 135.728 & 137.858 & 34.018 & 11 \\
& Aegean & 2736.000 & 159.156 & 71.544 & 39.890 & 8 \\
& Black Sea & 2693.235 & 109.180 & 113.509 & 27.364 & 17 \\
& Central Anatolia & 2673.385 & 124.852 & 85.381 & 31.292 & 13 \\
& Mediterranean & 2708.375 & 159.156 & 81.703 & 39.890 & 8 \\
& General & 2692.803 & 65.058 & 112.176 & & 76 \\
\hline & Eastern Anatolia & 1343.455 & 76.288 & 26.170 & 16.306 & 11 \\
& Southeastern Anatolia & 1281.375 & 65.058 & 64.790 & 19.120 & 8 \\
& Marmara & 1298.000 & 76.288 & 47.862 & 16.306 & 11 \\
& Aegean & 1294.250 & 52.333 & 64.107 & 19.120 & 8 \\
& Black Sea & 1324.000 & 59.845 & 53.120 & 13.116 & 17 \\
& Central Anatolia & 1329.077 & 76.288 & 60.632 & 14.999 & 13 \\
& Mediterranean & 1278.500 & 135.728 & 59.320 & 19.120 & 8 \\
& General & 1311.513 & 159.156 & 56.576 & & 76 \\
\hline
\end{tabular}

$\bar{X}$ : mean, $S_{X}$ : standard deviation, $S_{\bar{X}}$ : standard error

Table 6. MANOVA test results

\begin{tabular}{c|c|c|c|c|c|c|c}
\hline \multicolumn{2}{c|}{ Effect } & Values & F & Hypothesis df & Residual df & p & Power of test \\
\hline \multirow{4}{*}{ Region } & Pillai's Trace & 0.522 & 2.422 & 18 & 207 & 0.001 & 0.993 \\
& Wilks' Lambda & 0.546 & 2.518 & 18 & 190 & 0.001 & 0.991 \\
& Hotelling's Trace & 0.711 & 2.594 & 18 & 197 & 0.001 & 0.996 \\
& Roy's Largest Root & 0.490 & 5.634 & 6 & 69 & 0.001 & 0.995 \\
\hline
\end{tabular}

df: degrees freedom

$\mathrm{H}_{0}: \mu_{1}=\mu_{2}=\mu_{3} ; \mathrm{H}_{1}$ : At least one of the group mean values is different from the others. Since $\mathrm{p}=\mathrm{Sig}: 0.001<\alpha: 0.005, \mathrm{H}_{0}$ is rejected.

Within the framework of the results of the MANOVA test, Pillai's Trace, Wilks' Lambda, Hotelling's Trace and Roy's Largest Root test results displayed significant inter-regional differences in milk yields from 3 different breeds (indigenous, cross and culture breeds) $(\mathrm{p}<0.01)$. (This indicates that group mean vectors are significantly different.) Which means, according to Pillai's Trace statistic: $F=2.422, \mathrm{P}<0.001$; 
according to Wilks' Lambda statistic: $\mathrm{F}=2.518, \mathrm{P}<0.001$; According to Hotelling's Trace statistic: $\mathrm{F}=2.594, \mathrm{P}<0.001$; according to Roy's Largest Root statistic: $\mathrm{F}=5.694, \mathrm{P}<0.001$

Power of test values were very high. Power of test values for Pillai's Trace, Wilks' Lambda, Hotelling's Trace and Roy's Largest Root tests were 99.3\%, 99.1\%, 99.6\% and $99.5 \%$, respectively. Minimum absolute frequency corresponding to a power rating of $80 \%$ is generally favorable (Mendeş 2013). In this respect, the findings of these statistical analyses are favorable. As stated above, it is greater than $80 \%$ and the power of the test is high. More than $80 \%$ of the power of the test indicates that the analysis is appropriate.

Bonferroni and Tukey Multiple Comparison Tests were performed to determine the inter-regional differences regarding milk yield from each breed. Bonferroni and Tukey test results are presented in Table $7 a, b$ and $c$.

According to Bonferroni and Tukey test results, there were significant differences between the Eastern Anatolia-Marmara, Eastern Anatolia-Aegean, Southeastern Anatolia-Marmara and Southeastern Anatolia-Aegean regions with regards to average milk yield $(\mathrm{p}<0.05$ and $\mathrm{p}<0.01)$. In this respect, milk yield obtained from culture cattle in the Aegean and Marmara regions was much higher than the milk yield obtained from other regions. Milk yield obtained from culture cattle in the Eastern Anatolia and Southeastern Anatolia regions was lower. The highest milk yield was obtained from the Aegean and Marmara regions, respectively. Conditions of Aegean and Marmara regions in Turkey were observed to be favorable for culture cattle. Inter-regional differences regarding average milk yield from crossbreed and indigenous breed cattle were insignificant, indicating that all regions of Turkey are favorable for crossbreed and indigenous breed cattle.

Likewise, when the present situation (2018 year) can be also analyzed, the obtained results are summarized as follows. The effects of breeds and regions on milk yield in cattle are presented in Table 8. MANOVA Tests results for region (Table 8): Wilk's Lambda: 0.548, Pillai trace: 0.520, Roy's largest root test: 0.487, Hotelling trace: 0.705. Approximate F test: $12.370 *$ on 36 and 5677 d.f. (degrees freedom).

The results presented in Table 8 show that the highest mean milk yields were experienced in Aegean, Marmara and Central Anatolia (3926.755, 3889.264 and $3796.178 \mathrm{~kg}$ respectively), which are greater than the general mean $(3779.394 \mathrm{~kg})$ in culture cattle. The lowest mean milk yield was recorded of $3670.258 \mathrm{~kg}$ in Eastern Anatolia. The differences in mean yield owing to region are confirmed by the F-ratio for milk yield $(\mathrm{F}=4.923$ and $\mathrm{P}<0.001)$.

Aegean and Eastern Anatolia regions had the highest values for milk yield (2735.997 and $2715.171 \mathrm{~kg}$ respectively), while Southeastern Anatolia region recorded the least mean milk yield (2624.235) which is less than the general mean (2696.829 g) in crossbreed cattle. The difference between milk yields in crossbreed cattle by geographical regions was insignificant $(F=0.997$ and $\mathrm{P}>0.05)$.

Eastern Anatolia and Central Anatolia regions had the highest mean milk yield of native cattle (1343.499 and $1328.856 \mathrm{~kg}$ respectively) which are greater than the general mean $(1309.437 \mathrm{~kg})$, while Mediterranean region had a least mean milk yield of native cattle $(1278.477 \mathrm{~kg})$, less than the general mean. The difference between milk yields in native cattle by geographical regions was insignificant $(\mathrm{F}=1.952$ and $\mathrm{P}>0.05)$.

Bonferroni Multiple Comparison Test was applied to examine the inter-regional differences regarding milk yield from culture cattle. Bonferroni test results are presented in Table 9. 


$$
-14954 \text { - }
$$

Table 7a. Bonferroni and Tukey test results (for Culture)

\begin{tabular}{|c|c|c|c|c|c|c|}
\hline Group & Region & & \begin{tabular}{c|} 
Means \\
difference (I-J)
\end{tabular} & \begin{tabular}{|c|} 
Std. \\
error
\end{tabular} & $\begin{array}{c}\mathbf{P} \text { (for } \\
\text { Bonferroni) }\end{array}$ & $\begin{array}{l}\text { P (for } \\
\text { Tukey) }\end{array}$ \\
\hline \multirow{21}{*}{ Culture } & \multirow{6}{*}{ Eastern Anatolia } & Southeastern Anatolia & \begin{tabular}{|l|}
-7.352 \\
\end{tabular} & 63.245 & 0.999 & 0.999 \\
\hline & & Marmara & $-218.909^{*}$ & 58.037 & 0.007 & 0.006 \\
\hline & & Aegean & $-256.477^{*}$ & 63.245 & 0.003 & 0.002 \\
\hline & & Black Sea & -73.139 & 52.668 & 0.999 & 0.806 \\
\hline & & Central Anatolia & -125.881 & 55.760 & 0.570 & 0.280 \\
\hline & & Mediterranean & -82.977 & 63.245 & 0.999 & 0.844 \\
\hline & \multirow{5}{*}{ Southeastern Anatolia } & Marmara & $-211.557^{*}$ & 63.245 & 0.028 & 0.022 \\
\hline & & Aegean & $-249.125^{*}$ & 68.055 & 0.010 & 0.008 \\
\hline & & Black Sea & -65.787 & 58.357 & 0.999 & 0.917 \\
\hline & & Central Anatolia & -118.529 & 61.162 & 0.999 & 0.463 \\
\hline & & Mediterranean & -75.625 & 68.055 & 0.999 & 0.923 \\
\hline & \multirow{4}{*}{ Marmara } & Aegean & -37.568 & 63.245 & 0.999 & 0.997 \\
\hline & & Black Sea & 145.770 & 52.668 & 0.152 & 0.097 \\
\hline & & Central Anatolia & 93.028 & 55.760 & 0.999 & 0.639 \\
\hline & & Mediterranean & 135.932 & 63.245 & 0.738 & 0.336 \\
\hline & \multirow{3}{*}{ Aegean } & Black Sea & 183.338 & 58.357 & 0.052 & 0.038 \\
\hline & & Central Anatolia & 130.596 & 61.162 & 0.762 & 0.940 \\
\hline & & Mediterranean & 173.500 & 68.055 & 0.273 & 0.999 \\
\hline & \multirow{2}{*}{ Black Sea } & Central Anatolia & -52.742 & 50.148 & 0.999 & 0.940 \\
\hline & & Mediterranean & -9.838 & 58.357 & 0.999 & 0.999 \\
\hline & Central Anatolia & Mediterranean & 42.904 & 61.162 & 0.999 & 0.992 \\
\hline
\end{tabular}

Table 7b. Bonferroni test results (for Cross-bred)

\begin{tabular}{|c|c|c|c|c|c|c|}
\hline Group & Region & & $\begin{array}{c}\text { Means } \\
\text { difference (I-J) }\end{array}$ & \begin{tabular}{|c|} 
Std. \\
error
\end{tabular} & $\begin{array}{c}\mathbf{P} \text { (for } \\
\text { Bonferroni) }\end{array}$ & $\begin{array}{l}\text { P(for } \\
\text { Tukey) }\end{array}$ \\
\hline \multirow{21}{*}{ Cross-bred } & \multirow{6}{*}{ Eastern Anatolia } & Southeastern Anatolia & 90.932 & 52.425 & 0.999 & 0.596 \\
\hline & & Marmara & 15.364 & 48.109 & 0.999 & 0.999 \\
\hline & & Aegean & -20.818 & 52.425 & 0.999 & 0.999 \\
\hline & & Black Sea & 21.947 & 43.658 & 0.999 & 0.999 \\
\hline & & Central Anatolia & 41.797 & 46.221 & 0.999 & 0.971 \\
\hline & & Mediterranean & 6.807 & 52.425 & 0.999 & 0.999 \\
\hline & \multirow{5}{*}{ Southeastern Anatolia } & Marmara & -75.568 & 52.425 & 0.999 & 0.777 \\
\hline & & Aegean & -111.750 & 56.413 & 0.999 & 0.436 \\
\hline & & Black Sea & -68.985 & 48.373 & 0.999 & 0.786 \\
\hline & & Central Anatolia & -49.135 & 50.699 & 0.999 & 0.959 \\
\hline & & Mediterranean & -84.125 & 56.413 & 0.999 & 0.749 \\
\hline & \multirow{4}{*}{ Marmara } & Aegean & -36.182 & 52.425 & 0.999 & 0.993 \\
\hline & & Black Sea & 6.583 & 43.658 & 0.999 & 0.999 \\
\hline & & Central Anatolia & 26.434 & 46.221 & 0.999 & 0.997 \\
\hline & & Mediterranean & -8.557 & 52.425 & 0.999 & 0.999 \\
\hline & \multirow{3}{*}{ Aegean } & Black Sea & 42.765 & 48.373 & 0.999 & 0.974 \\
\hline & & Central Anatolia & 62.615 & 50.699 & 0.999 & 0.878 \\
\hline & & Mediterranean & 27.625 & 56.413 & 0.999 & 0.999 \\
\hline & \multirow{2}{*}{ Black Sea } & Central Anatolia & 19.851 & 41.569 & 0.999 & 0.999 \\
\hline & & Mediterranean & -15.140 & 48.373 & 0.999 & 0.999 \\
\hline & Central Anatolia & Mediterranean & -34.990 & 50.699 & 0.999 & 0.993 \\
\hline
\end{tabular}




$$
-14955 \text { - }
$$

Table 7c. Bonferroni test results (for Native)

\begin{tabular}{|c|c|c|c|c|c|c|}
\hline Group & Region & & \begin{tabular}{|c|} 
Means \\
difference (I-J)
\end{tabular} & $\begin{array}{c}\text { Std. } \\
\text { error }\end{array}$ & $\begin{array}{c}\mathbf{P} \text { (for } \\
\text { Bonferroni) }\end{array}$ & $\begin{array}{l}\text { P (for } \\
\text { Tukey) }\end{array}$ \\
\hline \multirow{21}{*}{ Native } & \multirow{6}{*}{ Eastern Anatolia } & Southeastern Anatolia & 62.080 & 25.129 & 0.335 & 0.186 \\
\hline & & Marmara & 45.455 & 23.060 & 0.999 & 0.442 \\
\hline & & Aegean & 49.205 & 25.129 & 0.999 & 0.450 \\
\hline & & Black Sea & 19.455 & 20.927 & 0.999 & 0.966 \\
\hline & & Central Anatolia & 14.378 & 22.155 & 0.999 & 0.995 \\
\hline & & Mediterranean & 64.955 & 25.129 & 0.249 & 0.147 \\
\hline & \multirow{5}{*}{ Southeastern Anatolia } & Marmara & -16.625 & 25.129 & 0.999 & 0.994 \\
\hline & & Aegean & -12.875 & 27.040 & 0.999 & 0.999 \\
\hline & & Black Sea & -42.625 & 23.187 & 0.999 & 0.527 \\
\hline & & Central Anatolia & -47.702 & 24.301 & 0.999 & 0.447 \\
\hline & & Mediterranean & 2.875 & 27.040 & 0.999 & 0.999 \\
\hline & \multirow{4}{*}{ Marmara } & Aegean & 3.750 & 25.129 & 0.999 & 0.999 \\
\hline & & Black Sea & -26.000 & 20.927 & 0.999 & 0.875 \\
\hline & & Central Anatolia & -31.077 & 22.155 & 0.999 & 0.799 \\
\hline & & Mediterranean & 19.500 & 25.129 & 0.999 & 0.987 \\
\hline & \multirow{3}{*}{ Aegean } & Black Sea & -29.750 & 23.187 & 0.999 & 0.857 \\
\hline & & Central Anatolia & -34.827 & 24.301 & 0.999 & 0.782 \\
\hline & & Mediterranean & 15.750 & 27.040 & 0.999 & 0.997 \\
\hline & \multirow{2}{*}{ Black Sea } & Central Anatolia & -5.077 & 19.925 & 0.999 & 0.999 \\
\hline & & Mediterranean & 45.500 & 23.187 & 0.999 & 0.448 \\
\hline & Central Anatolia & Mediterranean & 50.577 & 24.301 & 0.864 & 0.375 \\
\hline
\end{tabular}

Table 8. Summary of results of MANOVA test for regions across the milk yield

\begin{tabular}{c|c|c|c}
\hline Region & $\begin{array}{c}\text { Culture, milk yield } \\
\text { mean }(\mathbf{k g})\end{array}$ & $\begin{array}{c}\text { Crossbreed milk yield } \\
\text { mean }(\mathbf{k g})\end{array}$ & $\begin{array}{c}\text { Native milk yield mean } \\
\mathbf{( k g})\end{array}$ \\
\hline Mediterranean & 3753.273 & 2708.339 & 1278.477 \\
Southeastern Anatolia & 3677.567 & 2624.235 & 1281.331 \\
Eastern Anatolia & 3670.258 & 2715.171 & 1343.499 \\
Marmara & 3889.264 & 2699.791 & 1297.685 \\
Aegean & 3926.755 & 2735.997 & 1294.120 \\
Black Sea & 3756.949 & 2711.301 & 1315.155 \\
Central Anatolia & 3796.178 & 2673.365 & 1328.856 \\
General mean & 3779.394 & 2696.829 & 1309.437 \\
S.E.D. & 17.632 & 12.325 & 6.519 \\
F-ratio region & $4.923 * * *$ & $0.997 \mathrm{~ns}$ & $1.952 \mathrm{~ns}$ \\
\hline
\end{tabular}

$* * *, * *, *$ : significant differences at the $0.001,0.01$ and 0.05 level of significance respectively. ns stands for not significant at 5\% level of significance. S.E.D stands for standard error for differences. Power of test values for Pillai's Trace, Wilks' Lambda, Hotelling's Trace and Roy's Largest Root tests were $99.3 \%, 99.1 \%, 99.6 \%$ and $99.5 \%$, respectively. In short, the results of 2018 data and 2015 data were equal to each other

According to Bonferroni test results, there was significant differences between the Eastern Anatolia-Marmara, Eastern Anatolia-Aegean, Southeastern Anatolia-Marmara and Southeastern Anatolia-Aegean regions with regards to average milk yield $(\mathrm{p}<0.05$ and $\mathrm{p}<0.01$ ). Inter-regional differences regarding average milk yield from crossbreed and native cattle were insignificant. 
Table 9. Bonferroni test results (for culture)

\begin{tabular}{c|c|c|c|c|c|c|c}
\hline & $\begin{array}{c}\text { Eastern } \\
\text { Anatolia }\end{array}$ & $\begin{array}{c}\text { Southeastern } \\
\text { Anatolia }\end{array}$ & Marmara & Aegean & Black Sea & $\begin{array}{c}\text { Central } \\
\text { Anatolia }\end{array}$ & Mediterranean \\
\hline Eastern Anatolia & --- & --- & $* *$ & $* *$ & --- & --- & --- \\
Southeastern Anatolia & --- & --- & $*$ & $* *$ & --- & --- & --- \\
Marmara & $* *$ & $*$ & --- & --- & --- & --- & --- \\
Aegean & $* *$ & $* *$ & --- & --- & --- & --- & --- \\
Black Sea & --- & --- & --- & --- & --- & --- & --- \\
Central Anatolia & --- & --- & --- & --- & --- & --- & --- \\
Mediterranean & --- & --- & --- & --- & --- & --- & --- \\
\hline$* \mathrm{P}<0.05, * * \mathrm{P}<0.01$ & & & & &
\end{tabular}

Similar results were obtained in the MANOVA test for 2015 and 2018 data. In both data sets, the power of the test gave the same results. Bonferroni test gave the same results for 2015 and 2018 data in determining the difference of milk yield by region.

Çelik (2015) used the MANOVA method to analyze the inter-regional differences with regards to milk yield from small cattle. Research findings presented statistically significant inter-regional differences with regards to milk yield from hair goat and indigenous sheep. As for milk yield from hair goat, there were significant differences between Eastern Anatolia-Southeastern Anatolia, Marmara, Aegean and Mediterranean regions, Southeastern Anatolia-Marmara, Aegean and Mediterranean regions, MarmaraAegean regions, Middle Eastern Anatolia and Mediterranean regions, AegeanMediterranean regions, Middle Eastern Anatolia-Mediterranean regions and Mediterranean-Black Sea regions. As for milk yield from indigenous breed cattle, there were significant differences between Eastern Anatolia-Southeastern Anatolia, Marmara, Aegean, Middle Eastern, Mediterranean and Black Sea regions, Southeastern AnatoliaMarmara, Aegean, Middle Eastern, Mediterranean and Black Sea regions, MarmaraAegean regions, Middle Eastern Anatolia, Mediterranean and Black Sea regions, Aegean-Middle Eastern, Mediterranean and Black Sea regions and Middle Eastern Anatolia-Black Sea regions.

Indigenous, cross and culture breed animals in Turkey were compared with respect to 11 slaughtering and 18 carcass features and MANOVA analysis was performed. The differences among culture, indigenous and cross breeds were significant with regards to culture breeds (Kızıl and Aydoğan 2014).

In agricultural sciences, MANOVA test has been applied (Engeler and Reyer 2000, Woodward and Bauer 2007, Maposa et al. 2010, Turan 2011).

In this research, studies on other animal breeding data were analyzed using the MANOVA method.

\section{Conclusion}

In this research, milk yields from culture, cross and indigenous breed cattle in Turkey were analyzed by multivariate analysis (MANOVA) for 7 geographical regions. In this research, 7 groups (regions) were subjected to MANOVA test on the basis of 3 dependent variables (breeds). The cities of Kilis, Bingöl, Bitlis, Hakkari and Bartın were excluded from the research as they interrupted the observation values of the normality test. Analysis was performed for 76 cities and the observed outlier value was 
eliminated. After this stage, homogeneity test for the covariance matrices and sphericity test were presented with the aim to apply the MANOVA test. As $p=0.076>\alpha=0.05$ according to the results of the test, group covariance matrices were equal. As Approx $\chi^{2}=53.611$ and $\mathrm{p}<0.01$ according to the result of the Barlett's Test for Sphericity, MANOVA test was determined to be suitable for the analyzed data set. Representative statistical analysis was performed to show that milk yield from cross, culture and indigenous breeds varied on regional basis. While a higher milk yield was reported for cross breed cattle in the Aegean Region, the lowest milk yield was reported for the Eastern Anatolia Region. As for culture breed cattle, the highest milk yield was obtained in the Aegean Region whereas the lowest milk yield was obtained in the Southeastern Anatolia Region. As for indigenous breed cattle, the highest milk yield was obtained in the Eastern Anatolia Region whereas the lowest milk yield was obtained in the Mediterranean Region. According to the results of the Bonferroni test, milk yield differences from cross breed cattle were significant between the Eastern Anatolia-Aegean regions, Eastern Anatolia-Marmara regions, Southeastern AnatoliaAegean regions and Southeastern Anatolia-Marmara regions. The inter-regional differences observed in milk yield obtained from culture breed and indigenous breeds cattle were insignificant. In general, milk yield from cross and culture breeds cattle was higher in Aegean and Marmara regions whereas milk yield from indigenous breed cattle was higher in the Eastern Anatolia region. Statistical methods proved to be favorable in the research, enabling the essential hypotheses. Consequently, MANOVA test can be considered to be a powerful analysis method in this research. The MANOVA test was determined to be good predictors of the difference of milk yield between regions in agriculture. It can be recommended that the use multivariate statistical methods of such as MANOVA method will be beneficial in future studies in agriculture.

Acknowledgements. This study is derived from Mrs. Gamze Azak's master thesis.

\section{REFERENCES}

[1] Akman, N., Şen, A. Ö., Cedden, F. (2017): Türkiye'de sığır yetiştiriciliği. - Tarım Haftası 2017 Türkiye'nin Hayvansal Üretimi (Mevcut Durum ve Gelecek) Sempozyumu, 10-11 Ocak 2017, pp. 55-75, Ankara, Türkiye.

[2] Alpan, O., Arpacık, R. (1998): Sığır Yetiştiriciliği. - Medisan, Ankara.

[3] Alpar, R. (2011). Uygulamalı Çok Değişkenli İstatistiksel Yöntemler. - Detay Yayıncılık, Ankara.

[4] Bakır, G., Kaygisiz, A., Çilek, S. (2009): Milk yield of Holstein cattle reared at Tahirova State Farm in Balikesir Province in Turkey. - Journal of Animal and Veterinary Advances 8(11): 2369-2374.

[5] Bastin, C., Soyeurt, H., Gengler, N. (2013): Genetic parameters of milk production traits and fatty acid contents in milk for Holstein cows in parity 1-3. - J. Anim. Breed. Genet. 130: 118-127.

[6] Boğokşayan, H., Bakır, G. (2013): Determination of lifetime yield performance of Holstein cattle raised in Şanlıurfa Ceylanpınar farm. - Atatürk University Journal of the Agricultural Faculty 44(1): 75-81 (Turkish).

[7] Çelik, Ş. (2015): Investigation milk yield in small ruminants by region in Turkey. International Journal of Innovation Sciences and Research 4(10): 516-519. 
[8] Duru, S., Kumlu, S., Tuncel, E. (2012): Estimation of variance components and genetic parameters for type traits and milk yield in Holstein cattle. - Turk. J. Vet. Anim. Sci. 36(6): 585-591.

[9] Engeler, B., Reyer, H-U. (2000): Choosy females and indiscriminate males: mate choice in mixed populations of sexual and hybridogenetic water frogs (Rana lessonae, Rana esculenta). - Behavioral Ecology 12(5): 600-606.

[10] Everitt, B. S. (2001): Statistics for Psychologists. An Intermediate Course. - Lawrance Erlbaum Associates, Inc., New Jersey.

[11] FAO (2017): Food and Agriculture Organization of the United Nations. Live Animal Production. - http://faostat3.fao.org/download/Q/QL/E.

[12] Hsu, J. C. (1996): Multiple Comparisons. - CRS Press LLC, New York.

[13] Jeremy, D. F. A. (1974): General Model for Multivariate Statistical Analysis. - PrenticeHall International, Inc, USA.

[14] Johnson, R. A., Wichern, D. W. (2002): Applied Multivariate Statistical Analysis. Prentice Hall, Upper Saddle River, NJ.

[15] Hashemi, A., Nayebpoor, M. (2008): Estimates of genetic and phenotype parameters from milk production in Iran Holstein-Friesian cows. - Research Journal of Biological Sciences 3(6): 678-682.

[16] IBM Corp. Release (2015): IBM SPSS Statistics for Windows, Version 23.0. - IBM Corp, Armonk, NY.

[17] Irano, N., Braga Bignardi, A., El Faro, L., Luiz Santana M, Lúcia, C. V., Albuquerque, L. G. (2014): Genetic association between milk yield, stayability and mastitis in Holstein cows under tropical conditions. - Trop. Anim. Health Prod. 46: 529-535.

[18] Keskin, İ., Boztepe, S. (2011): Estimation of 305 days milk yield using partial milk yield in Holstein cattle. - Tekirdağ Ziraat Fakültesi Dergisi 8(1): 1-7.

[19] Khattab, A. S., Atil, H., Badawy, L. (2005): Variances of direct and maternal genetic effects form milk yield and first calving in a herd of Friesian cattle in Egypt. - Arch. Tierz. 48(1): 24-31.

[20] Kheirabadi, K., Alijani, S. (2014): Genetic parameters for milk production and persistency in the Iranian Holstein population by the multitrait random regression model. - Archiv Tierzucht 57(12): 1-12.

[21] Kızıl, S. H., Aydoğan, M. (2014): Evaluation of major cattle breeds in Turkey for slaughter and carcass traits using MANOVA and multidimensional scaling technique. Journal of Faculty of Veterinary Medicine, Erciyes University 11(1): 15-22.

[22] Kumlu, S., Akman, N. (1999): Milk yield and reproductive traits of Holstein Friesian breeding herds in Turkey - Lalahan Hayvanc1lık Araştırma Enstitüsü Dergisi 39(1): 1-15 (Turkish).

[23] Lehmann, E. L. (1986): Testing Statistical Hypotheses. Wiley Series in Probability and Mathematical Statistics. - Wiley, New York.

[24] Makgahlela, M. L., Banga, C. B., Norris, D., Dzama, K., Ng'ambi, J. W. (2007): Genetic correlations between female fertility and production traits in South African Holstein cattle. - South African Journal of Animal Science 37(3): 180-188.

[25] Maposa, D., Mudimu, E., Ngwenya, O. (2010): A multivariate analysis of variance (MANOVA) of the performance of sorghum lines in different agroecological regions of Zimbabwe. - African Journal of Agricultural Research 5(3): 196-203.

[26] Mendeş, M. (2013): Uygulamalı Bilimler İçin İstatistik ve Araştırma Yöntemleri. - Kriter Yayınevi, İstanbul.

[27] Oudah, E. Z. M., Zainab, A. K. (2010): Genetic evaluation for Friesan cattle in Egypt using single-trait animal model. - Journal Animal and Poultry Production, Mansoura University 1(9): 371-381.

[28] Pirzada, R. (2011): Estimation of genetic parameters and variance components of milk traits in Holstein-Friesian and British-Holstein dairy cows. - Kafkas Üniversitesi Veteriner Fakültesi Dergisi 17(3): 463-467. 


$$
-14959 \text { - }
$$

[29] Rao, C. R. (1973): Linear Statistical Inference and Its Applications. 2nd. Ed. - John Wiley \& Sons Inc, New York.

[30] Şahin, A., Ulutaş, Z. (2010): Genetic parameters of milk production and reproduction traits of Holstein cattle at a Tahirova State Farm conditions. - Kafkas Üniversitesi Veteriner Fakültesi Dergisi 16(6): 1051-1056.

[31] Şapdeniz, İ. (1993): A research on the economic analysis and the physical input requirements on the dairy enterprise of the Agriculture Faculty of Ankara University. Ankara University Graduate School of Natural and Applied Sciences Department of Agricultural Economics, Master's thesis, Ankara (Turkish).

[32] Sattar, A., Mirza, R. H., Niazi, A. A. K., Laitf, M. (2005): Productive and reproductive performance of Holstein-Friesian cows in Pakistan. - Parkistan Vet. J. 25(2): 75-81.

[33] Tekerli, M., Gündoğan, M. (2005): Effect of certain factors on productive and reproductive efficiency traits and phenotypic relationships among these traits and repeatabilities in West Anatolian Holsteins. - Turk J. Vet. Anim. Sci. (29): 17-22.

[34] Tuncel, E. (1994): Hayvan Islahı. - Uludağ Üniversitesi Ziraat Fakültesi Ders Notları No: 46, Bursa.

[35] Turan, H. (2011): Geometric Morphometric studies Trakya Region honeybees (Apis mellifera L.). - Ph.D. Thesis. Namık Kemal University Graduate School of Natural and Applied Sciences Main Science Division of Animal Science (Turkish).

[36] TSI (2015): Animal Production Statistics, Animal Products, Number of Milked Animals and Milk Production Quantity. - Turkish Statistical Institute, Ankara (Turkish). http://www.tuik.gov.tr/PreTablo.do?alt_id=1002 (accessed to 26.10.2016).

[37] Türky1lmaz, M. K. (2005): Reproductive characteristics of Holstein cattle reared in a private dairy cattle enterprise in Aydın. - Turk J. Vet. Anim. Sci. 29: 1049-1052.

[38] Woodward, L. E., Bauer, A. L. (2007): People and their pets: a relational perspective on interpersonal complementarity and attachment in companion animal owners. - Society and Animals 15: 169-189.

[39] Yaylak, E. (2003): Reasons for culling, herd life and productive life in Holstein cows Akdeniz Üniversitesi Ziraat Fakültesi Dergisi 16(2): 179-185 (Turkish).

[40] Yousefi-Golverdi, A., Hafezian, H., Chashnidel, Y., Farhadi, A. (2012): Genetic parameters and trends of production traits in Iranian Holstein population. - African Journal of Biotechnology 11(10): 2429-2435. 